\title{
Ribosomal Protein S6 Kinase (RSK)-2 as a central effector molecule in RON receptor tyrosine kinase mediated epithelial to mesenchymal transition induced by macrophage-stimulating protein
}

\author{
Qi Ma' ${ }^{1}$ Sunny Guin ${ }^{2}$, Snehal S Padhye ${ }^{2}$, Yong-Qing Zhou ${ }^{3}$, Rui-Wen Zhang ${ }^{4}$ and Ming-Hai Wang ${ }^{1,2^{*}}$
}

\begin{abstract}
Background: Epithelial to mesenchymal transition (EMT) occurs during cancer cell invasion and malignant metastasis. Features of EMT include spindle-like cell morphology, loss of epithelial cellular markers and gain of mesenchymal phenotype. Activation of the RON receptor tyrosine kinase by macrophage-stimulating protein (MSP) has been implicated in cellular EMT program; however, the major signaling determinant(s) responsible for MSPinduced EMT is unknown.

Results: The study presented here demonstrates that RSK2, a downstream signaling protein of the Ras-Erk1/2 pathway, is the principal molecule that links MSP-activated RON signaling to complete EMT. Using MDCK cells expressing RON as a model, a spindle-shape based screen was conducted, which identifies RSK2 among various intracellular proteins as a potential signaling molecule responsible for MSP-induced EMT. MSP stimulation dissociated RSK2 with Erk1/2 and promoted RSK2 nuclear translocation. MSP strongly induced RSK2 phosphorylation in a dose-dependent manner. These effects relied on RON and Erk1/2 phosphorylation, which is significantly potentiated by transforming growth factor (TGF)- $\beta 1$, an EMT-inducing cytokine. Specific RSK inhibitor SL0101 completely prevented MSP-induced RSK phosphorylation, which results in inhibition of MSP-induced spindle-like morphology and suppression of cell migration associated with EMT. In HT-29 cancer cells that barely express RSK2, forced RSK2 expression results in EMT-like phenotype upon MSP stimulation. Moreover, specific siRNA-mediated silencing of RSK2 but not RSK1 in L3.6pl pancreatic cancer cells significantly inhibited MSP-induced EMT-like phenotype and cell migration.

Conclusions: MSP-induced RSK2 activation is a critical determinant linking RON signaling to cellular EMT program. Inhibition of RSK2 activity may provide a therapeutic opportunity for blocking RON-mediated cancer cell migration and subsequent invasion.
\end{abstract}

\section{Background}

Epithelial to mesenchymal transition (EMT) is a biological process in polarized epithelial cells, which occurs in various physiological and pathological conditions [1]. Complete EMT is characterized by spindle-like cell morphology, loss of epithelial cellular markers such as E-cadherin, and gain of mesenchymal phenotype by

\footnotetext{
* Correspondence: minghai.wang@ttuhsc.edu

'Division of Cancer Biology at State Key Laboratory for Diagnosis \& Treatment of Infectious Diseases, First Affiliated Hospital, Zhejiang University College of Medicine, Hangzhou, 310003, China

Full list of author information is available at the end of the article

expressing filament proteins including vimentin and $\alpha$-smooth muscle actin $[1,2]$. Cells undergoing EMT are highly mobile and invasive [2,3]. During embryonic development, EMT enables cells to migrate or invade into neighboring tissues and maturate or differentiate into specialized cells $[1,2]$. In epithelial malignant progression, EMT has emerged as a critical player in regulating cancer cell invasive phenotype [4,5]. Acquiring EMT is a critical step for cancer cells to dissociate from a primary tumor mass and subsequently migrate and invade adjacent tissues for remote metastasis [4,5]. Recently, EMT has been linked with cancer stem-like 
phenotype in certain epithelia tumors [6,7]. As demonstrated, breast cancer cells express several cellular markers that resemble the stem-like phenotype during their progression towards EMT [6,7]. These observations highlight the importance of cellular EMT program in tumorigenic progression of cancer cells.

Development of EMT in cancer cells is regulated and precisely controlled at different cellular levels $[4,5]$. Various proteins such as receptor tyrosine kinases (RTK) [8-10], cytokine receptors $[11,12]$, intracellular signaling molecules [13,14], and transcriptional factors $[15,16]$ are involved in cellular EMT program. At the signaling level, RTK-mediated activation of extracellular signalregulated kinase $($ Erk1/2) has been implicated as a critical pathway for initiation of EMT $[13,17,18]$. Transforming growth factor (TGF)- $\beta 1$-stimulated TGF- $\beta$ receptor I/II and Smad signaling also play a pivotal role in induction of EMT $[11,19]$. Additional pathways such as Wnt- $\beta$-catenin signaling also have been implicated in EMT [20]. Convincing evidence indicates that signals coordinated among different pathways such as the RTKErk $1 / 2$ and TGF- $\beta 1$-Smad pathways maximize transdifferentiation of epithelial tumor cells towards EMT $[1,2]$. Moreover, such coordination raises the possibility that a converging signal for diverse pathways may exist, and may act as a central determinant controlling cellular EMT program.

Human $90 \mathrm{kDa}$ ribosomal S6 kinases (RSK) belong to a family of Ser/Thr kinases with two unique functional kinase domains [21]. The family consists of four isoforms (RSK1-4), of which RSK1 and RSK2 are currently under intensive investigation for their roles in cellular signaling [21-23]. In quiescent cells, RSK forms a protein-protein complex with Erk1/2 [24] and is considered to be a downstream signaling molecule of the Ras-Erk1/ 2 pathway [21]. Activation of RSK is featured by phosphorylation, dissociation from Erk1/2, and subsequent nuclear translocation [21]. Various extracellular factors including growth factors, cytokines, chemokines, peptide hormones, and neurotransmitters are known to directly activate RSK [21]. RSK phosphorylation occurs at multiple Ser and Thr residues through sequential steps by various kinases such as Erk1/2 [21-24]. Activated RSK phosphorylates many cytosolic and nuclear targets such as FLNA, BAD, DAPK, $227^{\mathrm{KIP} 1}$, and transcription factors including CREB, NF- $\kappa \mathrm{B}$, and NFAT3 [21-25]. Recently, RSK has emerged as a major player in the control of epithelial cell phenotype and motility [22]. RSK is indicated as a principal effector of the Ras-Erk1/2 pathway for eliciting a coordinated promotile/invasive program and phenotype in epithelial cells [22]. A genome-wide RNAi screen also has found that multiple proteins in various pathways depend on RSK for cellular migration [23]. These discoveries indicate that activation of RSK could be an essential convergent point for regulating cellular phenotypic changes and motile/invasive activities.

The present study sought to identify the major signaling molecule(s) responsible for EMT induced by macrophage-stimulating protein (MSP) [26], also known as hepatocyte growth factor (HGF)-like protein [27]. MSP is a serum-derived growth factor that specifically binds and activates the RON receptor tyrosine kinase $[28,29]$, a member of the MET proto-oncogene family [27]. Previous studies have observed that RON-mediated activation of the Ras-Erk1/2 pathway is critically important in transducing signals leading to EMT $[30,31]$. However, the downstream signaling molecule(s) that controls RON-mediated EMT is unknown. To facilitate this study, Martin-Darby canine kidney (MDCK) cells expressing human RON, which is known to show complete EMT $[30,31]$ was used as a model and a cell-shape based screen using various small chemical inhibitors was applied. By analyzing potential signaling proteins that are involved in MSP-induced EMT-like activities, we discovered that RSK2 is a principle effector molecule responsible for MSP-induced EMT in MDCK and human cancer cells. Evidence also indicates that RSK2 is responsible for TGF- $\beta 1$-induced EMT.

\section{Materials and methods Cell Lines and Reagents}

Martin-Darby canine kidney (MDCK) and human colon cancer HT-29 cells were purchased from ATCC (Manassas, VA). MDCK cells stably expressing RON (M-RON) were established as previously described [30]. Human pancreatic cancer L3.6pl cells were provided by Dr. G. E. Gallick (University of Texas M.D. Anderson Cancer Center, Houston, TX). Human MSP was provided by Dr. E. J. Leonard (National Cancer Institute, Bethesda, MD). Human transforming growth factor (TGF)- $\beta 1$ was from R\&D (Minneapolis, MN). Mouse monoclonal antibodies (mAb, clone $\mathrm{Zt} / \mathrm{g} 4$ ) and rabbit IgG antibody (R5029) were used as previously described [32]. Mouse mAb specific to phospho-tyrosine (PY-100), phosphoErk1/2, and other signaling proteins were from Cell Signaling (Danvers, MA). Mouse, rabbit, or goat IgG antibodies specific to panRSK, RSK1, RSK2, Snail, E-cadherin, vimentin, claudin-1, and F-actin were from BD Transduction Laboratories (Lexington, KY). PD98059 (PD), wortmannin (WT), U0126, SB203580, SB431524, rapamycin, and SL0101 were from CalBiochem (San Diego, CA). Small molecule inhibitor Compound-1 (CP-1) specific to human RON [33] was from Amgen (Thousand Oak, CA). SP600125, S31-201, XAV939, vismodegib, and SB431542 were from Selleck Chemicals (Houston, TX), and Cay10512 was from Cayman Chemicals (Ann Arbor, MI). 


\section{Transient expression of human RSK1 or RSK2 in HT-29 cells}

Transfection of cells with pcDNA3.1 containing RSK1 (pRSK1) or RSK2 cDNA (pRSK2) was performed using Lipofectamine as previously described [32]. Briefly, cells $\left(1 \times 10^{6}\right.$ cells in $60 \mathrm{~mm}$ diameter dish) were cultured overnight and then transfected with $3 \mu \mathrm{g} /$ dish of pRSK1 or pRSK2 vectors. The pRSK1/2 plasmids were provided by Dr. J. Chen (Emory University School of Medicine, Atlanta, GA). Cells transfected with an empty vector pcDNA3.1 were used as control. Transfected cells were incubated for $48 \mathrm{~h}$ and then processed for various biological assays.

\section{Immunoprecipitation and Western blot analysis}

These methods were performed as previously described [30]. Cellular proteins $(250 \mu \mathrm{g} / \mathrm{sample})$ were used for immunoprecipitation by $\mathrm{Zt} / \mathrm{g} 4$ ( $1 \mu \mathrm{g} / \mathrm{sample})$ coupled to protein G Sepharose beads. Individual proteins were detected using specific antibodies in Western blot analysis under reducing conditions. Membranes were reprobed with rabbit IgG antibody to $\beta$-actin to ensure equal sample loading [30].

\section{Cellular immunofluorescent analysis}

The method was performed as previously described [30]. To detect cytoplasmic or nuclear proteins, cells at $1 \times$ $10^{4}$ cells per well in a 24-well plate were cultured overnight and then stimulated for $24 \mathrm{~h}$ with MSP, TGF- $\beta 1$ or both in the presence or absence of various small chemical inhibitors. Cells were fixed with cold acetone and incubated with specific antibodies, followed by goat anti-mouse IgG coupled with FITC. Normal mouse IgG was used as the negative control. Cellular immunofluorescence was observed under Olympus BK71 microscope equipped with fluorescent apparatus as previously described [30].

\section{Methods for silencing RSK1 or RSK2 mRNA expression in L3.6pl cells}

Synthetic siRNA specific to human RSK1 or RSK2 were acquired from Dhamacon (Chicago, IL). To knockdown RSK expression, L3.6pl cells were cultured overnight and then transfected with RSK1 or RSK2 siRNA according to the manufacturer's instructions. After incubation for $48 \mathrm{~h}$, cells were washed and then processed for biochemical and biological analyses.

\section{Assays for cell morphological changes}

The assays were performed as previously described [30]. M-RON or other cells $\left(2 \times 10^{4} /\right.$ well in a 24 -well plate $)$ were cultured overnight and then stimulated with or without MSP ( $2 \mathrm{nM})$, TGF- $\beta 1(5 \mathrm{ng} / \mathrm{ml})$, or both at $37^{\circ}$ $\mathrm{C}$ for $24 \mathrm{~h}$. Cell morphological changes were observed and photographed using an Olympus BK71 inverted microscope equipped with CCD camera. The length of individual cells from experimental groups was determined by measuring 200 cells and results were expressed as elongation index and compared among various groups [30].

\section{Cell migration assays}

Wound healing assay was used to determine the ability of cells to migrate and fill the open space as previously described [32]. Cells were stimulated with MSP (2 nM), TGF- $\beta 1$ ( $5 \mathrm{ng} / \mathrm{ml})$ or both for 16 or $24 \mathrm{~h}$. The percentage of open space filled by migrated cells was calculated as previously described [32].

\section{Results}

Identification of RSK as an effector molecule in RONmediated EMT using cell-shape change based screen by various small chemical inhibitors

MSP induces complete EMT in MDCK cells, featured by spindle-like morphology, diminished E-cadherin expression, appearance of mesenchymal marker vimentin, and increased cell migration and invasiveness $[30,31]$. However, the major signaling molecule(s) linking RON signaling to these changes is unknown. To identify these molecules, we performed a MSP-induced cell-shape based screen using a panel of 12 small chemical inhibitors in M-RON cells. Intracellular proteins representing 10 signaling pathways such as Erk1/2, PI3 kinase, $\beta$-catenin, Stat $3, \mathrm{NF}-\kappa \mathrm{B}$ and others were targeted. These signaling proteins are known to be involved in cell morphological changes and motility [30,34-37]. Cell elongation index measured from spindle-like morphology was used to determine the effect of individual inhibitors (Table 1). Prevention of MSPinduced spindle-like morphology was not observed in M-RON cells treated with wortmannin, SB203580, SP600125, Cay10512, and S31-201, suggesting that signaling from these pathways was not involved in MSPinduced EMT. A moderate effect, based on changes in elongation index, was seen when rapamycin, vismodegib, and XAV-939 were applied, suggesting that signaling from Hedgehog, Wnt/ $\beta$-catenin, and FRAP/mTOR pathways played a role in MSP-induced EMT. As expected, inhibition of RON and Erk1/2 signals by CP1 and PD98059, respectively, completely blocked the effect of MSP, indicating the importance of the RONErk1/2 pathway in regulating EMT phenotype. An interesting result was the outcome of SL0101-mediated effects, which completely prevented MSP-induced EMT. SL0101 is a specific inhibitor of RSK and regulates various cellular activities [38]. The observed effects prompted us to determine if RSK is indeed a critical determinant in RON-mediated EMT. 
Table 1 Effect of Various Small Chemical Inhibitors on MSP-Induced Spindle-Like Morphologies in RON-Expressing MDCK cells*

\begin{tabular}{|c|c|c|c|c|}
\hline Small molecule inhibitors & Signal proteins inhibited & Amount used to treat cells & Cell elongation index & Preventive effect (\%) \\
\hline Control & N/A & N/A & $1.0 \pm 0.24$ & None \\
\hline MSP & none & $2.0 \mathrm{nM}$ & $3.12 \pm 0.47$ & N.D \\
\hline $\mathrm{CP}-1$ & RON & $100 \mu \mathrm{M}$ & $1.05 \pm 0.26$ & $98.4 \%$ \\
\hline PD98059 & MEK1/2 & $100 \mu \mathrm{M}$ & $1.03 \pm 0.31$ & $97.1 \%$ \\
\hline Wortmannin & Pl-3 kinase & $50 \mu \mathrm{M}$ & $2.9 \pm 0.41$ & $7.1 \%$ \\
\hline SB203580 & p38 MAP kinase & $50 \mu \mathrm{M}$ & $3.1 \pm 4.6$ & $0.6 \%$ \\
\hline SP600125 & $J N K 1,2,3$ & $5 \mu \mathrm{M}$ & $3.07 \pm 0.39$ & $1.6 \%$ \\
\hline Cay10512 & $\mathrm{NF}-\kappa \mathrm{B}$ & $5 \mu \mathrm{M}$ & $2.03 \pm 0.33$ & $39.4 \%$ \\
\hline S31-201 & Stat3 & $10 \mu \mathrm{M}$ & $1.25 \pm 0.34$ & $59.9 \%$ \\
\hline XAV-939 & Wnt/ $\beta$-catenin & $5 \mu \mathrm{M}$ & $2.16 \pm 0.32$ & $30.8 \%$ \\
\hline SL0101 & RSK & $50 \mu \mathrm{M}$ & $1.09 \pm 0.27$ & $97.1 \%$ \\
\hline Rapamycin & $\mathrm{FRAP} / \mathrm{mTOR}$ & $100 \mathrm{nM}$ & $2.69 \pm 0.25$ & $13.8 \%$ \\
\hline Vismodegib & Hedgehog & $1 \mu \mathrm{M}$ & $2.04 \pm 0.22$ & $34.6 \%$ \\
\hline SB431542 & TGF- $\beta 1$ receptor & $1 \mu \mathrm{M}$ & $2.97 \pm 0.24$ & $4.8 \%$ \\
\hline
\end{tabular}

*M-RON cells $\left(1 \times 10^{4}\right.$ cells/well) in DMEM containing $1 \%$ FBS were stimulated with $2 \mathrm{nM}$ of MSP in the presence of absence of individual small chemical inhibitors for $24 \mathrm{~h}$. Cell morphological changes were observed under microscope and photographed with CCD camera. Cell elongation index (CEI) was determined by measuring the length of individual adherent cells among various groups. CEI from control cells was set as one. The percentages of preventive effect were calculated by comparing with as the CEI from MSP-treated cells previously described [45]

MSP-induced RSK2 dissociation with Erk1/2 and its phosphorylation in correlation with Erk1/2 activation

RSK isoforms such as RSK1 or RSK2 associate with Erk1/2 in quiescent cells [21]. Dissociation between RSK and Erk1/2 requires phosphorylation [21]. To determine which RSK isoform(s) is regulated by MSP, M-RON cells were stimulated in the presence or absence of U0126, an inhibitor that blocks RSK dissociation with Erk1/2 [39]. TGF- $\beta 1$ was used as the control. RSK isoforms associated with Erk1/2 were determined by antiErk1/2 mAb immunoprecipitation followed by Western blot analysis using anti-RSK1 or RSK2 antibody. As shown in Figure 1A, RSK2 but not RSK1 was spontaneously associated with Erk1/2 in M-RON cells cultured in DMEM containing 1\% FBS. In contrast, interaction between RSK1 and Erk1/2 was not observed. It should be pointed out that RSK1 was expressed in M-RON cells (data not shown); however, Erk1/2 was not detected in anti-RSK1 immunoprecipitation. After MSP stimulation, RSK2-Erk1/2 complex dissociated. TGF-1 $\beta$ also induced RSK2-Erk1/2 dissociation although its effect was moderate. However, in cells treated with U0126, MSP or MSP plus TGF- $\beta 1$-induced dissociation of RSK2-Erk1/2 complex was blocked. Similar results were observed when immunoprecipitation was performed using anti-RSK2 mAb (data not shown). Taken together, these results suggested that MSP is capable of regulating RSK2 interaction with Erk $1 / 2$ and TGF- $\beta 1$ exerts a similar effect. MSP-induced dissociation could be the first step in regulating RSK2 activity.

The next experiment determined whether MSP activates RSK2 in association with Erk1/2 phosphorylation.
Again, TGF- $\beta 1$ was used for comparison. Results in Figure 1B showed the time-dependent RSK2 phosphorylation at Ser380 residue. MSP acted as a strong inducer of RSK2 phosphorylation, in which high levels of RSK2 phosphorylation were maintained for up to $30 \mathrm{~min}$ and then gradually reduced. The effect of TGF- $\beta 1$ on RSK2 phosphorylation was relatively weak, which peaked at about $5 \mathrm{~min}$ and then gradually diminished. In combined stimulation, TGF- $\beta 1$ significantly potentiated MSP-induced RSK2 phosphorylation. In this case, RSK2 phosphorylation was prolonged up to $60 \mathrm{~min}$, a significant increase compared to those stimulated by MSP or TGF- $\beta 1$ alone.

To correlate RSK2 phosphorylation with Erk1/2 activation, we determined MSP or TGF- $\beta 1$-induced Erk1/2 phosphorylation. Results in Figure $1 \mathrm{C}$ showed that MSP strongly induced Erk1/2 phosphorylation at Tyr 202/204 residues. Significant Erk1/2 phosphorylation was seen as early as $5 \mathrm{~min}$, peaked at $15 \mathrm{~min}$, and then gradually reduced to the baseline at $240 \mathrm{~min}(4 \mathrm{~h})$. Such a timedependent kinetic effect correlated well with the time course of RSK2 phosphorylation (Figure 1B). In contrast, TGF- $\beta 1$-induced Erk1/2 phosphorylation occurred at relatively later stages and had a delayed time course. The curve did not seem to correlate with the time course of RSK2 phosphorylation (Figure 1B). Again, TGF- $\beta 1$ potentiated MSP-induced Erk1/2 phosphorylation. A strong and long-lasting effect on Erk1/2 phosphorylation was achieved when both stimuli were used (Figure $1 \mathrm{C}$ ). These results, together with those shown in Figure 1B, demonstrated that MSP is a strong inducer of RSK2 phosphorylation. The kinetics of 


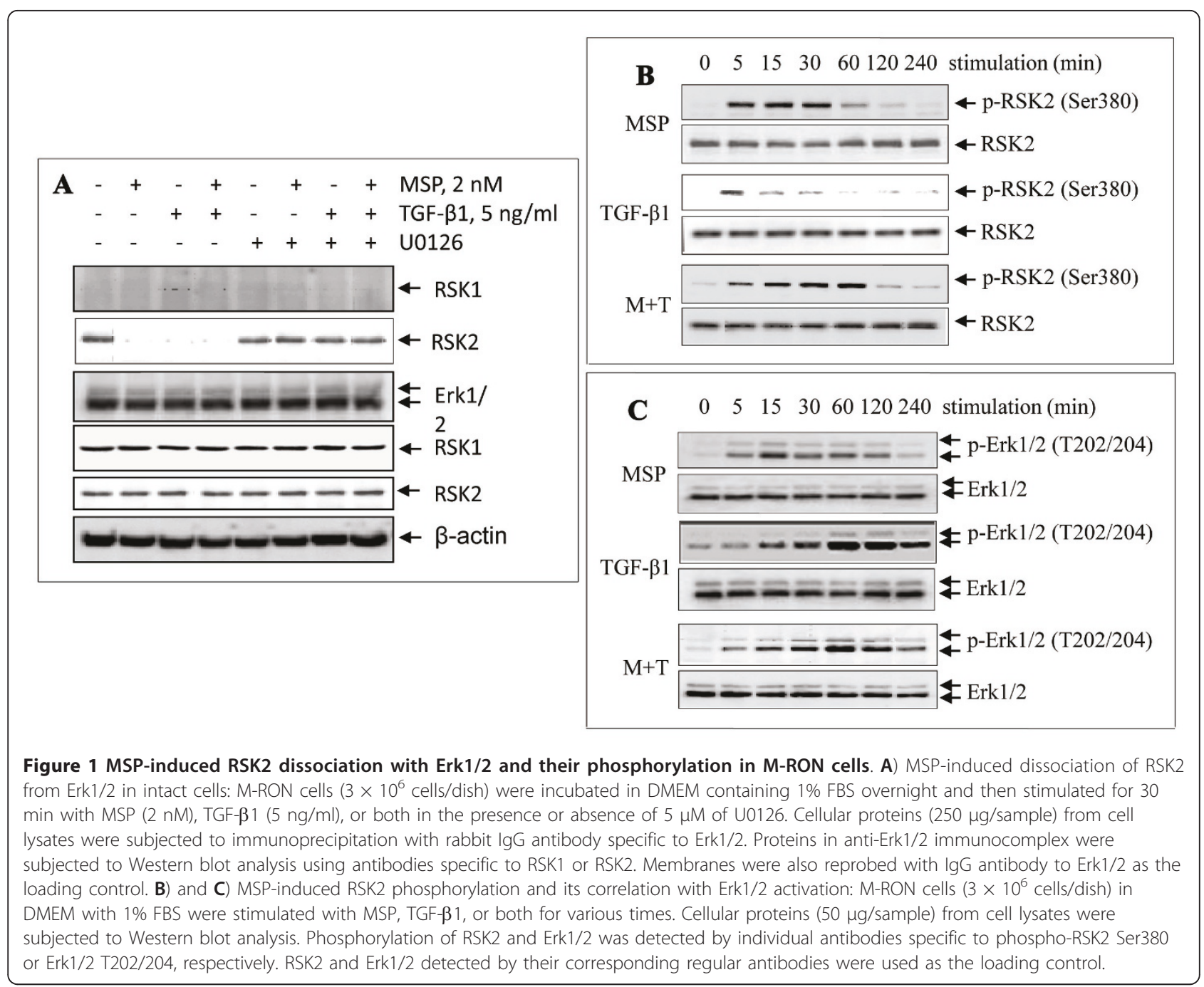

phosphorylation between Erk1/2 and RSK2 correlated well upon MSP stimulation. TGF- $\beta 1$ showed a moderate stimulating effect on RSK2 phosphorylation. It induced Erk1/2 phosphorylation but showed a relatively delayed time-course. However, TGF- $\beta 1$ potentiated MSPinduced RSK2 and Erk1/2 phosphorylation.

\section{Prevention of MSP-induced RSK2 activation by small chemical inhibitors specific to RON and Erk1/2}

To determine if MSP-induced RSK2 phosphorylation is indeed mediated by RON and Erk1/2 signaling, M-RON cells were stimulated in the presence or absence of specific RON inhibitor CP-1 and Erk1/2 inhibitor PD98059. RSK2 phosphorylation was determined by Western blot analysis. CP-1 inhibited MSP-induced RON phosphorylation in a dose-dependent manner (Figure 2A). CP-1 treatment also led to diminished Erk1/2 phosphorylation. Significantly, CP-1 inhibited MSP-induced RSK2 phosphorylation in a dose-dependent manner. We also observed the inhibitory effect of CP-1 in cells stimulated with MSP plus TGF- $\beta 1$. However, levels of inhibition, as shown by the phosphorylation levels of Erk1/2 and RSK2, were not as strong as those shown in cells stimulated with MSP alone. Dramatic inhibition was only seen when high concentrations of CP-1 (up to $300 \mu \mathrm{g} /$ $\mathrm{ml}$ ) were used. Results from PD98059 experiments confirmed that inhibition of Erk1/2 had no effect on MSPinduced RON phosphorylation. However, levels of Erk1/ 2 phosphorylation were diminished by PD98059 in a dose-dependent manner (Figure 2B). Moreover, PD98059 inhibited MSP or MSP plus TGF- $\beta 1$-induced RSK2 phosphorylation in a dose-dependent manner. Thus, the results in Figure 2 demonstrated that by inhibiting RON or Erk1/2 activation, both $\mathrm{CP}-1$ and PD98059 are able to prevent MSP or MSP plus TGF$\beta 1$-induced RSK2 phosphorylation, suggesting that activated RON and Erk1/2 signaling is required for MSP-induced RSK2 phosphorylation. 

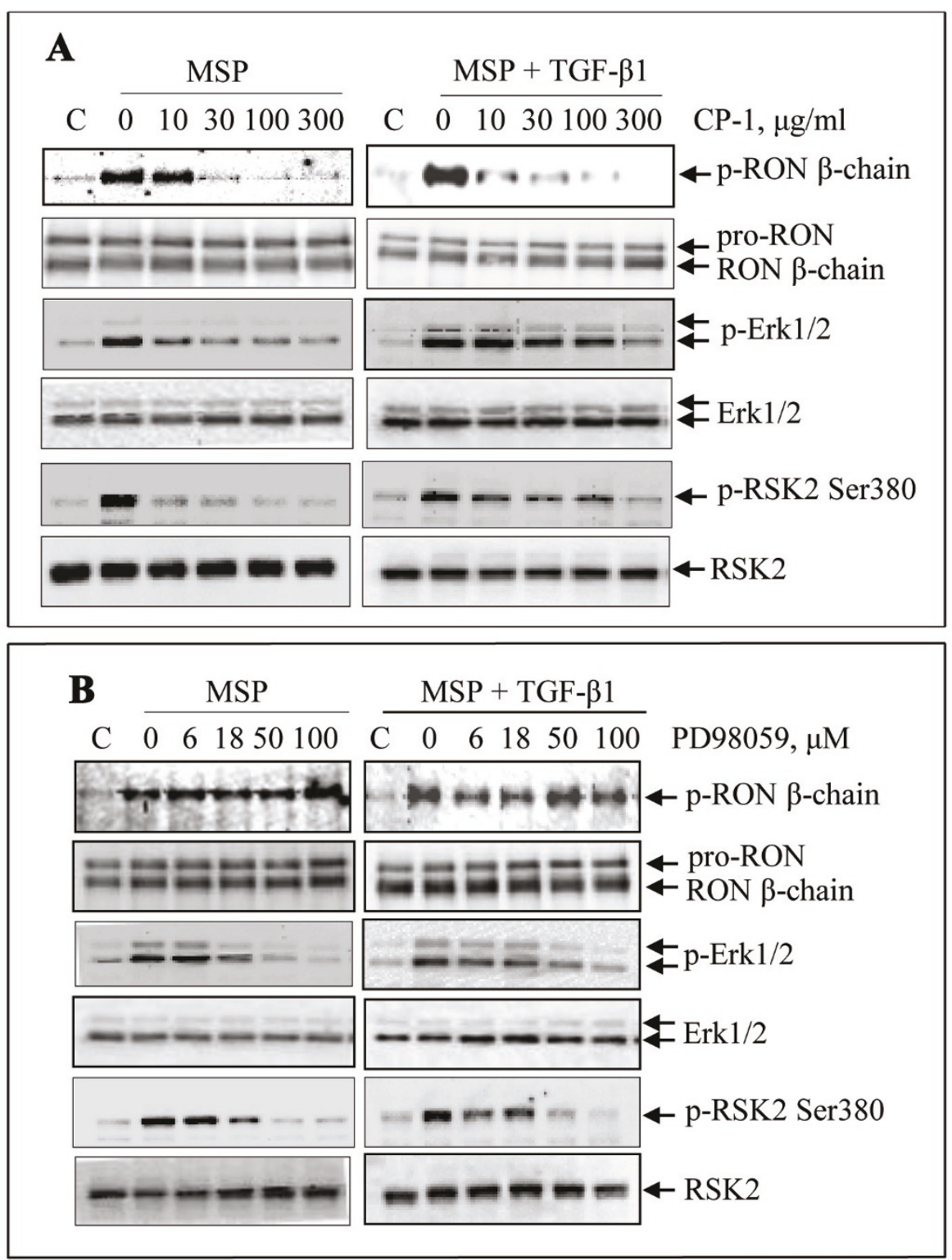

Figure 2 Inhibitory effect of CP-1 and PD98059 on MSP or MSP plus TGF- $\beta 1$-induced RSK2 phosphorylation: M-RON cells $\left(3 \times 10^{6}\right.$ cells per dish) in DMEM with $1 \%$ of FBS were first treated with CP-1 or PD98059 for 10 min followed by stimulation with MSP (2 nM) or MSP plus TGF- $\beta 1$ ( $5 \mathrm{ng} / \mathrm{ml})$. Cells were collected $30 \mathrm{~min}$ after stimulation. Phosphorylated RON was determined by Western blot analysis after Zt/g4 immunoprecipitation of cell lysates ( $250 \mu \mathrm{g}$ proteins/sample). Phosphorylated Erk1/2 and RSK2 were directly determined by Western blot analysis using specific antibodies, respectively. Membranes were also reprobed with individual antibodies to detect non-phosphorylated proteins as the loading controls. Data shown here are from one of two experiments with similar results.

\section{Effect of MSP on RSK2 nuclear translocation and phosphorylation}

To further determine the effect of MSP on RSK2, we studied RSK2 nuclear translocation in comparison with Erk1/2 activation. Cells were stimulated by MSP or MSP plus TGF- $\beta 1$ for various times and cytoplasmic and nuclear proteins were prepared. RSK2 was mainly detected in cytoplasmic fraction in non-stimulated
M-RON cells. A small amount of RSK2 was also present in nuclear proteins (Figure 3A). This pattern was similar to that of Erk1/2, in which Erk1/2 in both cytoplasmic and nuclear fractions was observed. Upon MSP stimulation, the amounts of RSK in nuclear fraction were dramatically increased in a time-dependent manner. Phosphorylation was observed not only in cytosolic but also in nuclear RSK2. Again, a similar pattern was 
documented for Erk1/2, in which phosphorylated Erk1/2 was detected in nuclear proteins. Results in Figure $3 \mathrm{~B}$ demonstrated that MSP in combination with TGF- $\beta 1$ induced RSK2 nuclear translocation and phosphorylation. This effect was accompanied by Erk1/2 phosphorylation. A major difference was that the time course for both RSK2 and Erk1/2 phosphorylation lasted longer in MSP and TGF- $\beta 1$ co-stimulated cells than in cell treated with MSP alone.

We further validated results from Western blotting by studying cellular RSK and Erk1/2 distribution using DSU confocal microscope image analysis. Cytoplasmic and nuclear RSK2 and Erk1/2 were detected by antiRSK2 or Erk1/2 immunofluorescent analysis. As shown in Figure 3C, RSK2 immunofluorescent staining was detected in both cytoplasmic and nuclear compartments in control M-RON cells. Upon MSP stimulation, increased nuclear fluorescent intensity was observed, indicating nuclear accumulation of RSK2 and Erk1/2. We noticed that RSK2 nuclear staining appeared as a pattern of condensed granules. Cellular distribution of Erk1/2 in control cells was similar to that of RSK2. MSP induced Erk1/2 nuclear translocation with increased nuclear fluorescent intensity. The patterns of Erk $1 / 2$ nuclear staining were in a relatively diffused manner. Consistent with these observations, RSK 2 nuclear accumulation also was observed in cells stimulated with MSP plus TGF- $\beta 1$ with granule-like staining pattern. Again, Erk1/2 accumulated in nucleus with combined stimulation but distributed in a more diffused pattern. These results, together with those in Figure 3A and 3B, demonstrated that distribution and phosphorylation between RSK2 and Erk1/2 upon MSP stimulation exist.

\section{Preventive effect of RSK2 inhibitor SL0101 on MSP or MSP plus TGF- $\beta 1$-induced EMT}

To determine if RSK2 is indeed an effector molecule, we studied the effect of SL0101 on MSP-induced EMT. We also used TGF- $\beta 1$ to induce EMT for evaluation. Results in Figure 4A showed that MSP induced spindle-like morphological changes in M-RON cells. As expected, this effect was prevented by CP-1 and PD98059, but not by PI-3 kinase inhibitor wortmannin. Consistent with results shown in Table 1, SL0101 significantly prevented
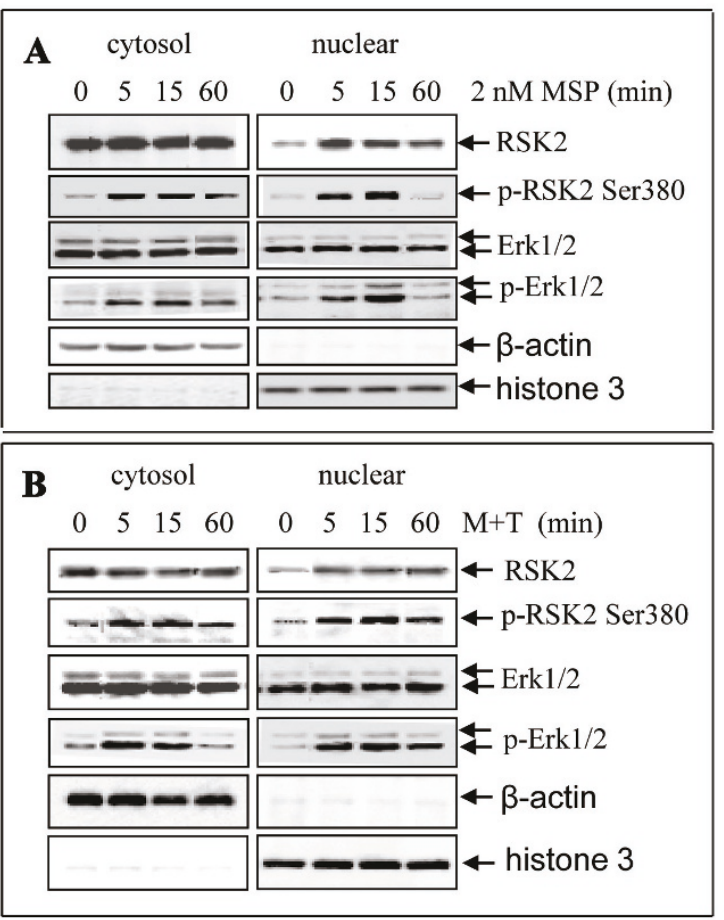

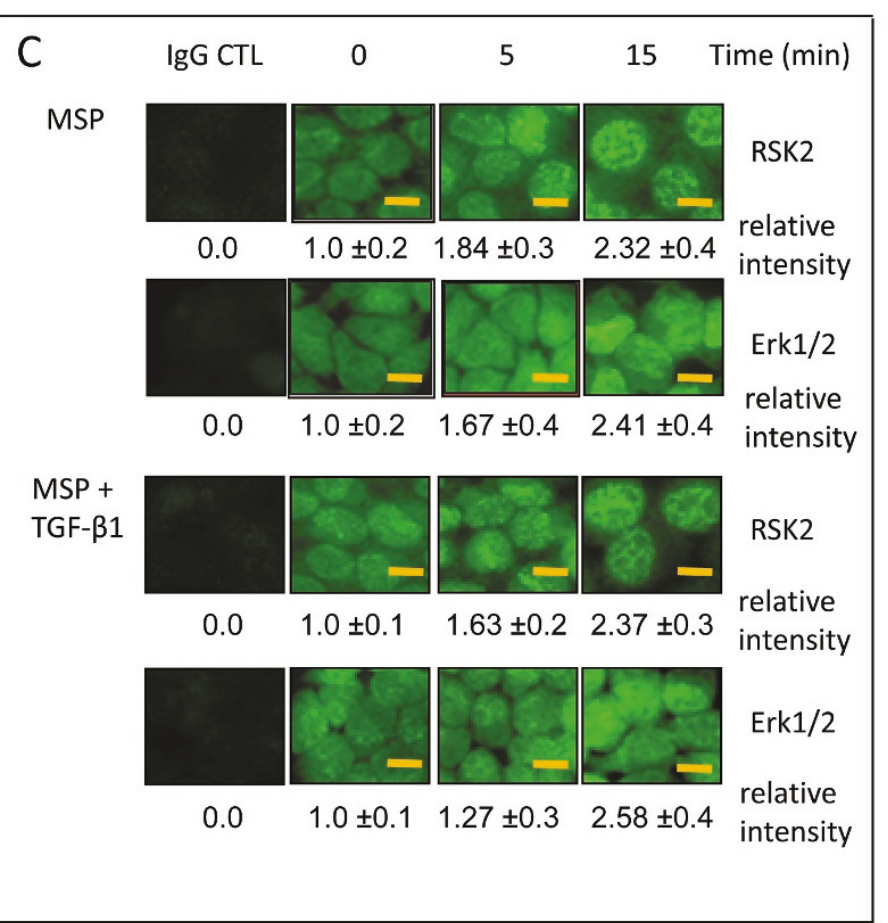

Figure 3 Effect of MSP on RSK2 phosphorylation and its nuclear translocation: M-RON cells ( $3 \times 10^{6}$ cells per dish) in DMEM with $1 \%$ FBS were stimulated with MSP (2 nM), TGF- $\beta 1$ ( $5 \mathrm{ng} / \mathrm{ml})$, or MSP plus TGF- $\beta 1$ for various times. Cellular proteins (50 $\mu \mathrm{g} / \mathrm{sample}$ ) from cell lysates were subjected to Western blot analysis using antibodies specific to regular or phospho-RSK (Ser380) and Erk1/2. A) MSP induced RSK2 phosphorylation and nuclear translocation. B) Effect of MSP and TGF- $\beta 1$ on RSK2 phosphorylation and nuclear translocation. C) Immunofluorescent analysis of MSP or MSP plus TGF- $\beta$ 1-induced RSK2 nuclear translocation. M-RON cells were stimulated with MSP or MSP plus TGF- $\beta 1$ v for various times. Cells were fixed with cold acetone, blocked with $1 \%$ BSA, followed by incubation with antibody specific to RSK2. FITC coupled rabbit anti-mouse lgG was used as the detecting antibody. Immunofluorescence was observed by Olympus BT71 microscope equipped with fluorescent apparatus as previously described [45]. Scale bars represent $5 \mu \mathrm{m}$. 


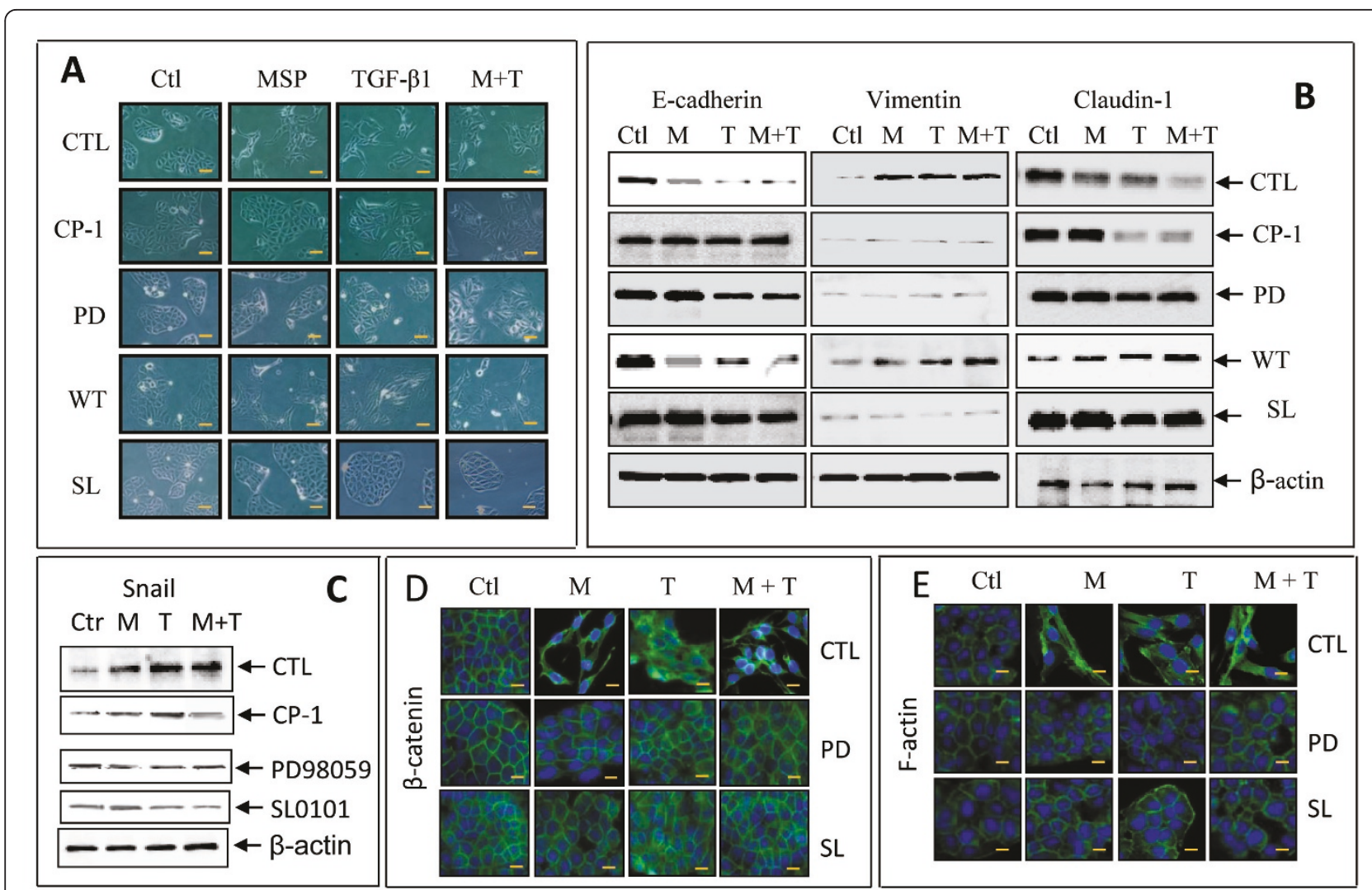

Figure 4 Preventive Effect of RSK inhibitor SL0101 on MSP and MSP plus TGF- $\beta 1$-induced EMT: M-RON cells $\left(1 \times 10^{5}\right.$ cells/well in a $24-$ well plate) were incubated overnight and then stimulated with MSP (2 nM), TGF- $\beta 1(5 \mathrm{ng} / \mathrm{ml})$, or both at $37^{\circ} \mathrm{C}$ for $24 \mathrm{~h}$. Small chemical inhibitors specific to RON (CP-1, 100 nM), Erk1/2 (PD98059, $100 \mu \mathrm{M}$ ), PI-3kinase (wortmannin, $50 \mu \mathrm{M})$ ), and RSK (SL0101, $50 \mu \mathrm{M})$ were added simultaneously. A) Cell morphological changes were observed and photographed using Olympus BK71 microscope equipped with CCD camera. Scale bars represent $20 \mu \mathrm{m}$. B) Cellular proteins (50 $\mathrm{mg}$ per sample) were also prepared for Western blot analysis. Expression of E-cadherin, claudin-1, and vimentin was determined by using specific antibodies. Membranes were also reprobed with antibodies to actin as the loading control. C) Transcription repressor Snail in nuclear proteins was detected by Western blot analysis using anti-Snail antibody. Preparation of nuclear factions was performed as previously described [45]. D) and E) $\beta$-catenin redistribution and F-actin reorganization was determined by immunofluorescent analysis [35] using antibodies specific to $\beta$-catenin and F-actin, respectively. Data shown here are from one of three experiments with similar results. Scale bars represent $10 \mu \mathrm{m}$.

MSP-induced spindle-like morphology. SL0101 also prevented TGF- $\beta 1$-induced cell shape changes, but its effect was not complete. Moreover, the synergistic effect of MSP and TGF- $\beta 1$ in cell morphology was affected by SL0101 (Figure 4A). In all these cases, altered cell morphology was significantly restored to original epithelial appearance.

Experiments were then conducted to determine if SL0101 regulates E-cadherin, claudin-1, and vimentin expression (Figure 4B). CP-1, PD98059, and wortmannin were included as controls. SL0101 completely prevented MSP-induced reduction of E-cadherin. Sl0101 also prevented increased vimentin expression. These observations concurred with results from cells treated with CP1 and PD98059, but not with wortmannin, Additionally, SL0101 treatment restored claudin-1 expression, a protein essential for epithelial tight junction formation [40].
Preventive effect of SL0101 also was seen in M-RON cells stimulated with TGF- $\beta 1$ and MSP plus TGF- $\beta 1$. In both cases, expression of E-cadherin and claudin-1 was restored and induction of vimentin was blocked.

Activation of transcription repressor Snail is known to suppress E-cadherin expression leading to EMT [16,41]. Analysis of nuclear proteins from MSP-treated M-RON cells by Western blotting revealed that inhibition of RSK2 by SL0101 had a negative effect on RON-mediated Snail expression (Figure 4C). SL0101 prevented MSP-induced Snail expression in M-RON cells. Reduced Snail expression was also seen in MSP-stimulated cells treated with CP-1 and PD98059. Again, the action of SL0101 was not limited to MSP, as SL0101 also prevented TGF$\beta 1$-induced Snail expression. We want to emphasize that Snail expression induced by TGF- $\beta 1$ was sensitive to PD98059 but not to CP-1 (Figure 4C). 
We further studied the effect of SL0101 on MSP and TGF- $\beta 1$-induced redistribution of $\beta$-catenin and F-actin. Both proteins play a role in $\mathrm{RON}$-mediated EMT $[30,35]$. Results in Figure 4D showed the redistribution of $\beta$-catenin from cell membrane to cytoplasmic compartment upon MSP and TGF- $\beta 1$ stimulation. SL0101 prevented MSP and TGF- $\beta 1$-induced $\beta$-catenin redistribution and cytoplasm-associated $\beta$-catenin disappeared after addition of SL0101. A similar effect also was observed in cells treated with PD98059. In both cases, $\beta$-catenin was redistributed to cell membrane along with typical epithelial morphology. The effect of SL0101 on F-actin distribution was very similar to those of $\beta$-catenin after treatment with MSP, TGF- $\beta 1$, and both (Figure $4 \mathrm{E})$. F-actin was mainly associated with cell membrane with a certain amount of cytoplasmic distribution. MSP and TGF- $\beta 1$ caused increased accumulation of F-actin in cytoplasm. This effect was prevented by SL0101, which restored F-actin distribution to its original membrane-associated appearance. This effect was also accompanied by the reappearance of epithelial morphology.

We performed the wound-healing assay to determine if SL0101 can prevent MSP-induced migration of MRON cells. Increased migration is a function associated with EMT. Results in Figure 5 showed that M-RON cells had spontaneous migration (35.0\%) and MSP stimulation further enhanced cell motility (86.0\%).
Treatment of cells with SL0101 alone had no effect on cell migration; however, SL0101 significantly prevented MSP or MSP-plus TGF- $\beta 1$-induced cell migration. The percentages of cell migration induced by MSP and MSP plus TGF- $\beta 1$ (86.0\% and $89.3 \%$, respectively) were dramatically reduced after SL0101 treatment $(38.4 \%$ and $45.2 \%$, respectively). We observed inhibition levels that were comparable to those treated with CP-1 and PD98059. Thus, results in Figure 4 and 5 demonstrated that SL0101 inhibition of RSK prevented MSP and TGF- $\beta 1$-induced spindle-like morphology accompanied with redistribution of $\beta$-catenin and F-actin. E-cadherin and claudin- 1 expression reappeared and vimentin expression was blocked. These activities were associated with the inhibition of transcription repressor Snail expression. Moreover, SL0101 significantly impairs MSP and TGF- $\beta 1$ induced cell migration, which is a function associated with EMT.

\section{Effect of increased RSK expression in MSP-induced EMT-like activity in cancer cells}

To study the effect of RSK2 on MSP-induced EMT in more detail, two human cancer cell lines L3.6pl and HT-29 were selected based on their differences in RSK1 and RSK2 levels and similarities in RON and TGF- $\beta$ receptor expression (Figure 6A). Pancreatic cancer L3.6pL cells expressed regular levels of RSK1 and RSK2. MSP and TGF- $\beta 1$ stimulation caused elongated cell

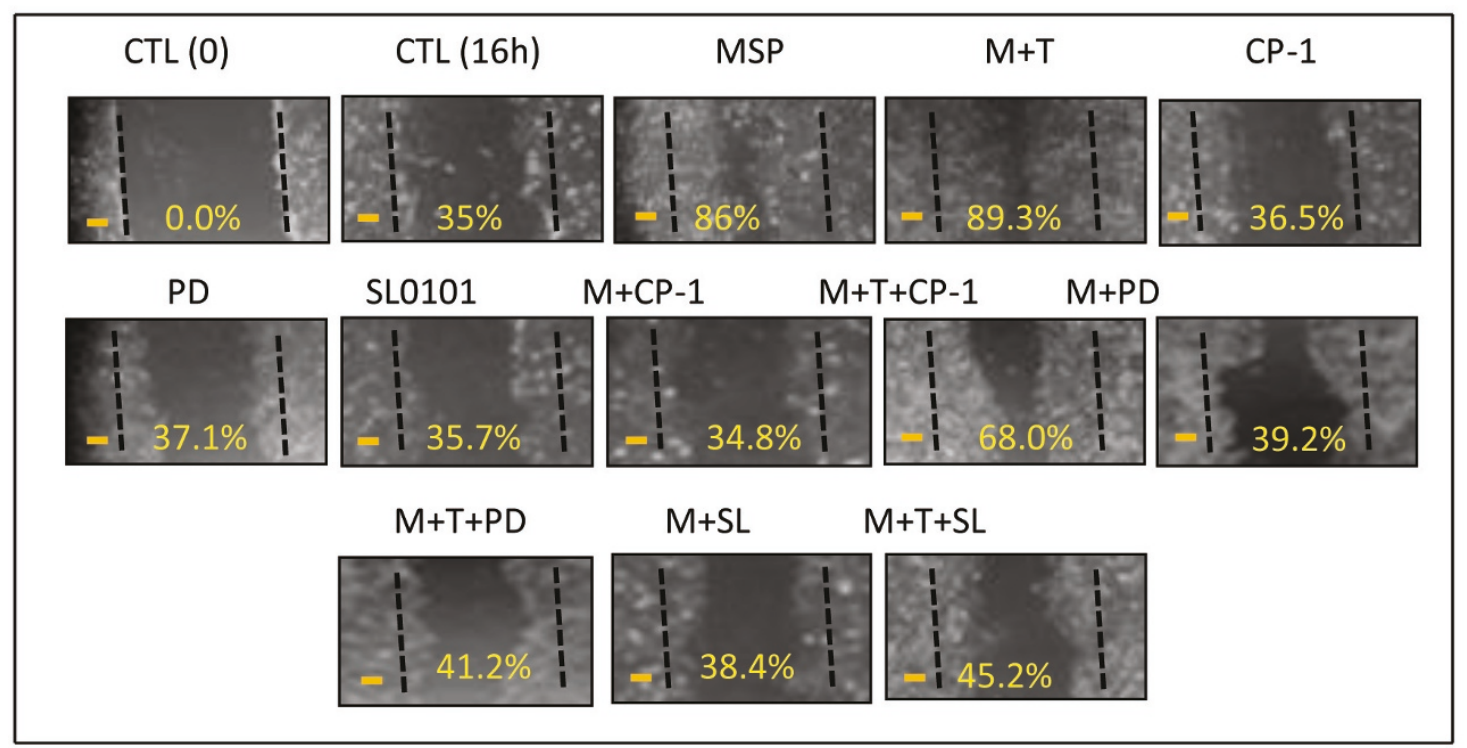

Figure 5 Effect of SL0101 on MSP or MSP plus TGF- $\beta$ 1-induced cell migration. The monolayer of M-RON cells in DMEM with 1\% FBS) were wounded with a plastic tip and then stimulated with MSP $(2 \mathrm{nM})$, TGF- $\beta 1(5 \mathrm{ng} / \mathrm{ml})$, or both in the presence or absence of CP-1 (300 $\mu \mathrm{g} / \mathrm{ml})$,

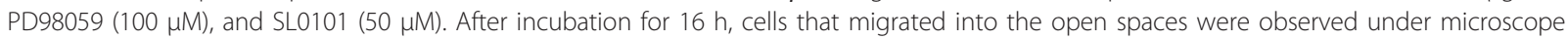
and photographed. Wounded areas that covered by migrated cells were calculated as previously described [35]. Data shown here are from one of two experiments with similar results. Scale bars represent $50 \mu \mathrm{m}$. 


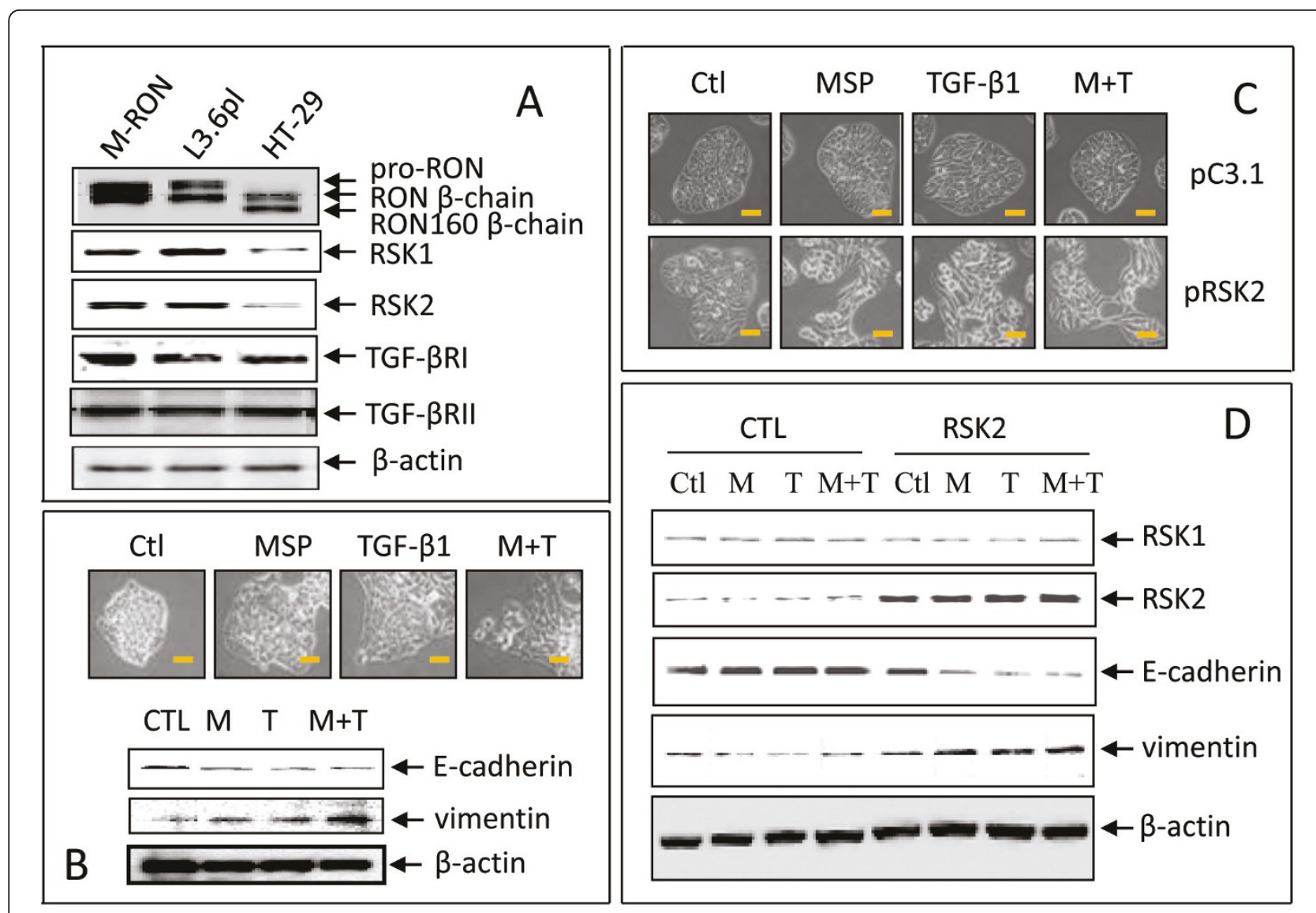

Figure 6 Requirement of RSK2 expression in MSP and TGF- $\beta 1$ induced EMT-like activity in cancer cells. A) Expression of RON, RSK1, RSK2, and TGF- $\beta$ receptors in human cancer L3.6pl and HT-29 cells. Cell lysates ( $50 \mu \mathrm{g} / \mathrm{sample}$ ) were subjected to Western blot analysis using antibodies specific to individual proteins. B) MSP induces EMT-like activities in pancreatic cancer L3.6pl cells. L3.6pl cells $\left(0.5 \times 10^{6}\right.$ cells per dish) were cultured overnight and then stimulated at $37^{\circ} \mathrm{C}$ with MSP $(2 \mathrm{nM})$, TGF- $\beta 1(5 \mathrm{ng} / \mathrm{ml})$, or both for $24 \mathrm{~h}$. Cell morphological changes were observed by Olympus microscope and photographed with CCD camera. E-cadherin and vimentin expression was determined by Western blot analysis using cell lysates as described previously [35]. Actin was used as the loading control. Scale bars represent $20 \mu \mathrm{m}$. C) Forced RSK2 expression facilitates MSP and TGF-1-induced EMT-like activity in HT-29 cells. Cells $\left(2 \times 10^{6}\right.$ cells per dish) were transiently transfected with $3 \mu \mathrm{g}$ of pRKS2 plasmid or control vector pcDNA3.1 for $48 \mathrm{~h}$ and then stimulated with MSP and TGF- $\beta 1$ as described above. Morphological changes and expression of individual proteins were determined as described in A. Scale bars represent 20 MM. D) RSK2 expression diminishes E-cadherin expression and increases vimentin expression. HT-29 cells were transiently transfected with pRSK2 plasmid for $48 \mathrm{~h}$ followed by stimulation with MSP, TGF- $\beta 1$ or both for $24 \mathrm{~h}$. Cell lysates were subjected to Western blot analysis using antibodies specific to E-cadherin or vimentin. $\beta$-actin was used as the loading control. Data shown here are from one of two experiments with similar results.

morphology, reduced E-cadherin expression, and increased vimentin expression (Figure 6B). Combined MSP and TGF- $\beta 1$ treatment further enhanced the modulating effect on E-cadherin and vimentin expression. These results indicated that L3.6pl cells show EMT-like phenotypic changes after MSP and TGF- $\beta 1$ stimulation and a synergistic activity between RON and TGF- $\beta$ RI/II signaling in induction of EMT-like phenotype.

HT-29 cells expressed extremely low levels of RSK1 and RSK2 (Figure 6A). Treatment of cells with MSP, TGF- $\beta 1$ or both caused barely any morphological changes (data not shown). Western blot analysis also failed to observe any changes in E-cadherin and vimentin expression in MSP plus TGF- $\beta 1$-stimulated HT-29 cells (data not shown). However, RSK2 overexpression by pRSK2 plasmid transfection resulted in cell morphological changes after MSP stimulation (Figure $6 \mathrm{C})$. We observed similar changes when transfected HT29 cells were stimulated with TGF- $\beta 1$ or MSP plus TGF- $\beta 1$. Analysis of E-cadherin and vimentin expression in pRSK2-transfected HT-29 cells confirmed that MSP and TGF- $\beta 1$ stimulation caused E-cadherin reduction and vimentin induction (Figure 6D). These results suggested that increasing RSK2 expression renders HT-29 cells responsive to MSP and TGF- $\beta 1$-induced EMT-like activities. 

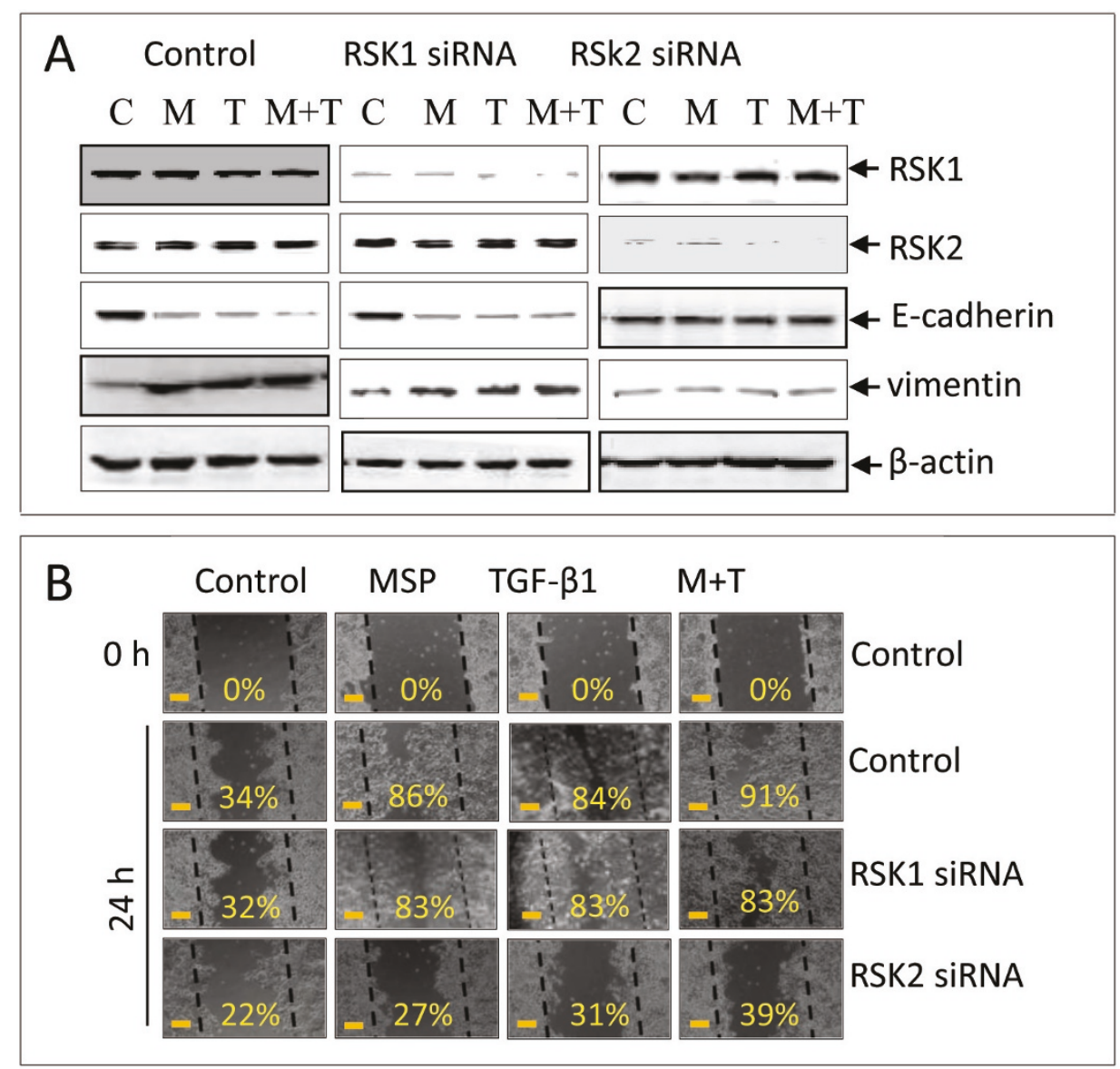

Figure 7 Effect of siRNA-mediated RSK2 knockdown on MSP and TGF- $\beta 1$-induced EMT-like activities and cell migration by L3.6pl cells: A) Knockdown of RSK2 expression by specific siRNA restored E-cadherin expression and prevented vimentin induction. L3.6pl cells $\left(2 \times 10^{6}\right.$ cells per dish) were cultured overnight and transiently transfected with $3 \mu \mathrm{g} /$ dish of pcDNA3.1, pRSK1, or pRSK2 by using lipofectamine (Invitrogen). Transfected cells were cultured for $72 \mathrm{~h}$ and then lysed with lysis buffer. Cellular proteins ( $50 \mathrm{\mu g}$ per sample) were subjected to Western blot analysis as described previously using antibodies specific to RSK1, RSK2, E-cadherin, and vimentin, respectively. The membranes were also reprobed with rabbit IgG to actin as the loading control. B) L3.6pl cells were transiently transfected with pcRSK1 or pcRSK2 for $48 \mathrm{~h}$ followed by stimulation with MSP, TGF- $\beta 1$, or both as described above. The wound healing assay was performed after a 24 h-incubation to determine the levels of cell migration. The percentage of wounded area covered by migrated cells was determined as previously described [45]. Data shown here are from one of three experiments with similar results. Scale bars represent $50 \mu \mathrm{m}$.

\section{Effect of RSK specific siRNA on MSP-induced cell migration}

To further confirm the role of RSK2, we transiently transfected L3.6pl cells with specific siRNA to silence RSK1 or RSK2 mRNA expression. Results in Figure 7A showed that siRNA specific to RSK1 effectively silenced RSK1 expression but had no effect on RSK2 expression. RSK2 specific siRNA only silenced RSK2 expression but had no effect on RSK1 expression. These results confirmed specificities of siRNA used to silence RSK1 and RSK2, respectively. Analysis of MSP and TGF- $\beta 1$-regulated epithelial and mesenchymal proteins revealed that silencing RSK1 expression did not prevent MSP and TGF- $\beta 1$-induced reduction of E-cadherin and induction of vimentin. In contrast, knockdown of RSK2 expression restored E-cadherin expression and prevented vimentin induction. We also observed these effects in cells treated with TGF- $\beta 1$ and MSP plus TGf- $\beta 1$, indicating that RSK2 was required for MSP and TGF- $\beta 1$-induced EMTlike biochemical changes.

We further studied the effect of siRNA mediated RSK2 knockdown on cell migration by the wound healing assay (Figure 7B). L3.6pl cells showed spontaneous migration, which was further enhanced by MSP stimulation. The amount of open space covered by migrated cells increased from $34 \%$ up to $86 \%$. Knockdown of RSK1 had little effect on spontaneous cell migration, but silencing RSK2 expression showed a moderate effect 
on spontaneous cell migration. In MSP-induced cell migration, silencing RSK1 expression did not impair MSP-induced cell migration, as more than $80 \%$ of the open space was still covered by migrated cells. In contrast, MSP-induced cell migration was significantly impaired in RSK2 siRNA treated cells. In this case, only $27 \%$ of the open space was covered by migrated cells, which was similar to spontaneous migration. TGF- $\beta 1$ induced cell migration was not affected by knockdown of RSK1. The inhibitory effect was only observed in cells treated with specific RSK2 siRNA. Moreover, we observed that silencing RSK2 expression also impairs cell migration synergized by combined MSP and TGF$\beta 1$ stimulation. Thus, silencing RSK2 but not RSK1 by specific siRNA decreases MSP-induced cell migration in L3.6pl cancer cells.

\section{Discussion}

The purpose of this study is to identify the major signaling molecule(s) that controls MSP-induced EMT in epithelial cells. Altered RON expression and activation contribute to malignant progression of various epithelial cancers [30,42]. RON is overexpressed in various types of primary cancer samples including those from colon, breast, and pancreas [42]. Aberrant RON activation also causes increased tumor cell proliferation, matrix invasion, and drug resistance [42]. Currently, the role of MSP and RON in regulating EMT under physiological conditions is largely unknown. In contrast, MSP-induced RON activation or RON overexpression have been shown to induce EMT in various cancer cells including colon, breast, and pancreas [30,31,43-45]. The changes to mesenchymal phenotype in RON-activated tumor cells have been considered as a molecular basis for increased tumor malignancy including cell migration, matrix invasion, and distance metastasis [42]. Several upstream signaling proteins such as Erk1/2 have been implicated in MSP-induced EMT [30,31]; however, the major effector molecule(s) that transduces RON signals leading to EMT is still unknown. Intracellular proteins such as $\beta$-catenin and NF- $\kappa \mathrm{B}$ have been identified as effector molecules in MSP-induced EMT [45-47]. Nevertheless, their significance is often limited to particular cell models. Thus, identification of the major signaling molecule(s) is important not only for an understanding of the cellular mechanisms of EMT, but also for the development of potential therapies that target cancer cell migration and invasion.

Results from this study indicate that RSK2 is a major determinant bridging RON signaling to EMT. This conclusion is supported by the following evidence. First, inhibition of RSK, as indicated in the cell-shape based screen by using specific RSK inhibitor SL0101, completely prevented MSP-induced spindle-like morphology.
Inhibitors that target other proteins such as NF- $\kappa \mathrm{B}$, Stat3, and hedgehog, except CP-1 and PD98059, only showed moderate effect. This indicates that RSK activation is essential in MSP-induced spindle-like morphology. Second, MSP-induced RON activation dissociated RSK2 from Erk1/2, and caused RSK2 phosphorylation and subsequent nuclear translocation. These data suggest that MSP is a strong RSK activation inducer, which is mediated by RON transduced signals. Third, RSK2 phosphorylation relied on the RON-Erk1/2 pathways. Inhibition of RON or Erk $1 / 2$ by their corresponding small chemical inhibitors prevented MSP-induced RSK2 phosphorylation. These data also established that RSK is a downstream molecule in the MSP-RON-Erk1/2 axis. Fourth, inhibition of RSK2 by SL0101 blocked MSPinduced spindle-like changes, which is evident by the redistribution of $\beta$-catenin to the membrane and reorganization of f-actin to original epithelial morphology. Moreover, in SL0101 treated cells, epithelial morphology was completely restored with re-expression of E-cadherin and claudin-1, reduction of vimentin expression, and minimized transcription repressor Snail expression. Fifth, SL0101 prevention of RSK2 activation decreased MSP and TGF- $\beta 1$-induced cell migration. As shown in the wound healing assay, RON-mediated cell migration was dramatically reduced upon inhibition of RSK2 by SL0101. Finally, RSK2 overexpression led to EMT-like phenotypes in colon HT-29 cancer cells that express extremely low levels of RSK2. Moreover, specific siRNAmediated RSK2 knockdown prevented MSP and TGF$\beta 1$-induced EMT-like activity in pancreatic cancer L3.6pl cells. Considering these factors, we concluded that SRK2 is the major effector molecule in RONmediated EMT.

In reviewing cellular mechanisms underlying EMT in different types of epithelial and cancerous cells, it is apparent that various proteins belonging to multiple signaling pathways are involved in regulating EMT $[4,5]$. The identified proteins include Erk1/2, PI-3 kinase, AKT, p38, $\beta$-catenin, NF- $\kappa$ B, Stat 3 , Smad, and others [11-20]. The typical example is the Erk1/2-mediated signaling event that leads to EMT $[17,22]$. Specifically, Erk2 but not Erk1 has been found to be critical in EMT induction, which is mediated by DEF motif-dependent signaling events [17]. Currently, the signaling proteins participated in EMT represent at least seven different signaling pathways. The involvement of such diverse signaling proteins suggests the possible existence of a central signaling molecule that acts as a switch for initiation of EMT in epithelial cells. In supporting this notion, recent studies has shown that RSK acts as a principal effector molecule in coordinating cellular EMT program in epithelial cells [22]. Genome-wide RNAi screen also has discovered that multiple proteins in a 
broad range of pathways depend on RSK for induction of cellular migration program [23]. We observed that RSK2 activation is critical in controlling EMT in MDCK and cancer cells mediated by MSP. Moreover, RSK2 is also required for TGF- $\beta 1$-induced EMT. The involvement of RSK2 in two different signaling pathways suggests that RSK2 acts as a potential central molecule in regulating EMT and cell migration. In other words, RSK2 activation acts as the convergent point for both RON-Erk $1 / 2$ and TGF- $\beta$ receptor I/II-Smad pathways leading to complete EMT.

The importance of RSK2 in RON signaling also establishes a critical link to other signaling molecules observed in MSP-induced EMT and cell migration. Activation of Erk1/2 is required for MSP-induced EMT $[30,31]$. As a downstream molecule of the Erk $1 / 2$ pathway, RSK2 transduces MSP-induced and Erk1/2 mediated signal for EMT as demonstrated in this study. In breast cancer cells, NF- $\kappa \mathrm{B}$ activation is implicated in RON-mediated cellular motility [47]. RSK is known to activate NF- $\kappa$ B by phosphorylating NF- $\kappa$ B inhibitor $\mathrm{I} \kappa \mathrm{B} \alpha$ and inducing its degradation [48]. This finding suggests that the observed NF- $\kappa \mathrm{B}$ activity in MSP-stimulated breast cancer cells could be channeled through RON-activated RSK2. In colon cancer cells stimulated by MSP, increased $\beta$-catenin accumulation contributes to spindle-like morphologies with increased migration [35]. RSK2 activation is known to increase steady-state of $\beta$-catenin through phosphorylation and inhibition of a $\beta$-catenin regulator GSK-3 $\beta$ [49]. These activities imply that the RON-mediated inhibition of GSK-3 $\beta$ [35] could be caused by MSP-induced RSK2 activation. The role of MSP-activated AKT activity in cell migration is another example [34]. Currently, evidence of direct RSK activation by AKT is not available. In contrast, studies have indicated that RSK is a mediator of growth factorinduced activation of PI-3 kinase and AKT in epithelial cells [50]. Thus, it is likely that MSP-induced AKT activation is mediated by RSK. Such activation facilitates AKT in regulating MSP-induced cell migration. Considering all these facts, we reasoned that RSK is centered in MSP-induced and RON-mediated EMT with increased cell migration.

Studies sing pancreatic L3.6pl and colon HT-29 cells provide additional evidence showing the importance of RSK2 in MSP-induced EMT-like activity. First, we confirmed results derived from the MDCK cell model and demonstrated that RSK2 but not RSK1 is selectively involved in regulating RON-mediated EMT and associated cell migration. In the $\mathrm{L} 3.6 \mathrm{pl}$ cell model, only RSK2 specific siRNA prevented MSP-induced EMT and cell migration. Second, we demonstrated that MSPinduced EMT-like phenotype is dependent on RSK2 expression and activation. In $\mathrm{L} 3.6 \mathrm{pl}$ cells that express regular levels of RSK1 and RSK2, MSP induces EMTlike phenotypes featured by elongated cell morphology, reduced E-cadherin expression, and increased vimentin expression (Figure 6). In contrast, these activities were not observed in HT-29 cells that express minimal levels of RSK1 and RSK2. HT-29 cells express both RON and oncogenic variant RON160 and both regulate HT-29 cell growth [51]. However, MSP fails to induce EMT and migration in HT-29 cells, which provides indirect evidence indicating the role of RSK2 in MSP-induced EMT and cell migration. Rescue experiments by pRSK2 cDNA transfection confirmed this theory. As shown in Figure 6C, RSK2-transfected HT-29 cells underwent spindle-like morphological changes with diminished Ecadherin and increased vimentin expression. Additional evidence supporting this notion comes from studies using RSK2-specific siRNA. Knockdown of RSK2 expression significantly inhibited MSP-induced L3.6pl cell migration (Figure 7), which reaffirms the importance of RSK2 in MSP-induced EMT. The final observation is that the effect of RSK2 on EMT is not limited to MSP. TGF- $\beta 1$-induced EMT and cell migration also were affected by inhibition of RSK2. HT-29 cells with minimal RSK2 expression did not respond to TGF- $\beta 1$. Spindle-like morphology was only seen when RSK2 is overexpressed. Western blot analysis of E-cadherin and vimentin expression in RSK2 deficient and transfected HT-29 cells confirmed that this is the case. RSK2 siRNA based analysis of cell migration further demonstrated that knockdown of RSK2 expression significantly impairs TGF- $\beta 1$-induced L3.6pl cell migration.

\section{Conflict of interests}

The authors declare that they have no competing interests.

\section{Acknowledgements}

This work was supported in part by National Institutes of Health grant R01 CA91980 and Amarillo Area Foundation (MH Wang), and R01CA112029 and R01 CA121211 (RW Zhang). We thank Drs. E. J. Leonard for MSP; I. Dussault (Amgen, Thousand Oaks, CA) for small molecule inhibitor Compound-1; J. Chen (Emory University School of Medicine, Atlanta, GA) for plasmids containing human RSK1 and RSK2. The assistance of Ms. S. Denney (Scientific editor, Texas Tech University Health sciences Center School of Pharmacy, Amarillo, TX) in editing the manuscript is greatly appreciated.

\section{Author details}

${ }^{1}$ Division of Cancer Biology at State Key Laboratory for Diagnosis \& Treatment of Infectious Diseases, First Affiliated Hospital, Zhejiang University College of Medicine, Hangzhou, 310003, China. ${ }^{2}$ Cancer Biology Research Center and Department of Biomedical Sciences, School of Pharmacy, Texas Tech University Health Sciences Center, Amarillo, TX 79106, USA.

${ }^{3}$ Department of Neurosurgery, First Affiliated Hospital, Zhejiang University College of Medicine, Hangzhou, 310003, China. ${ }^{4}$ Department of Pharmaceutical Sciences, School of Pharmacy, Texas Tech University Health Sciences Center, Amarillo, TX 79106, USA. 


\section{Authors' contributions}

QM performed the majority of biochemical analysis and biological experiments. SG and SSP did cellular immunofluorescent studies. HPY worked on anti-RON antibody production and characterization, RWZ, YQZ, and MHW participated in the design of the study and drafted the manuscript. All authors have read and approved the final manuscript.

Received: 1 February 2011 Accepted: 28 May 2011

Published: 28 May 2011

\section{References}

1. Thiery JP, Acloque H, Huang RY, Nieto MA: Epithelial-mesenchymal transitions in development and disease. Cell 2009, 139:871-890.

2. Kalluri $R$, Weinberg RA: The basics of epithelial-mesenchymal transition. J Clin Invest 2009, 119:1420-1428.

3. Kalluri REMT: When epithelial cells decide to become mesenchymal-like cells. J Clin Invest 2009, 119:1417-1419.

4. Singh A, Settleman J: EMT, cancer-stem cells and drug resistance: an emerging axis of evil in the war on cancer. Oncogene 2010, 29:4741-4751.

5. Christiansen JJ, Rajasekaran AK: Reassessing epithelial to mesenchymal transition as a prerequisite for carcinoma invasion and metastasis. Cancer Res 2006, 66:8319-8326.

6. Mani SA, Guo W, Liao MJ, Eaton EN, Ayyanan A, Zhou AY, Brooks M, Reinhard F, Zhang CC, Shipitsin M, Campbell LL, Polyak K, Brisken C, Yang J, Weinberg RA: The epithelial-mesenchymal transition generates cells with properties of stem cells. Cell 2008, 133:704-715.

7. Polyak K, Weinberg RA: Transitions between epithelial and mesenchymal states: acquisition of malignant and stem cell traits. Nat Rev Cancer 2009, 9:265-273

8. Chaffer CL, Brennan JP, Slavin JL, Blick T, Thompson EW, Williams ED: Mesenchymal-: role of fibroblast growth factor receptor-2. Cancer Res 2006, 66:11271-11278.

9. Ohashi S, Natsuizaka M, Wong GS, Michaylira CZ, Grugan KD, Stairs DB, Kalabis J, Vega ME, Kalman RA, Nakagawa M, Klein-Szanto AJ, Herlyn M, Diehl JA, Rustgi AK, Nakagawa H: Epidermal growth factor receptor and mutant p53 expand an esophageal cellular subpopulation capable of epithelial-to-mesenchymal transition through ZEB transcription factors. Cancer Res 2010, 70:4174-4184.

10. Gjerdrum C, Tiron C, Høiby T, Stefansson I, Haugen H, Sandal T, Collett K, Li S, McCormack E, Gjertsen BT, Micklem DR, Akslen LA, Glackin C, Lorens JB: Axl is an essential epithelial-to-mesenchymal transitioninduced regulator of breast cancer metastasis and patient survival. Proc Natl Acad Sci USA 2010, 107:1124-1129.

11. Wendt MK, Smith JA, Schiemann WP: Transforming growth factor- $\beta$ induced epithelial-mesenchymal transition facilitates epidermal growth factor-dependent breast cancer progression. Oncogene 2010, 29:6485-6498.

12. Yan C, Grimm WA, Garner WL, Qin L, Travis T, Tan N, Han YP: Epithelial to mesenchymal transition in human skin wound healing is induced by tumor necrosis factor-alpha through bone morphogenic protein-2. Am J Pathol 2010, 176:2247-258.

13. Shin SY, Rath O, Zebisch A, Choo SM, Kolch W, Cho KH: Functional roles of multiple feedback loops in extracellular signal-regulated kinase and Wnt signaling pathways that regulate epithelial-mesenchymal transition. Cancer Res 2010, 70:6715-6724.

14. Martin JC, Herbert BS, Hocevar BA: Disabled-2 downregulation promotes epithelial-to-mesenchymal transition. Br J Cancer 2010, 103:1716-1723.

15. Mak P, Leav I, Pursell B, Bae D, Yang X, Taglienti CA, Gouvin LM, Sharma VM, Mercurio AM: ERbeta impedes prostate cancer EMT by destabilizing HIF-1alpha and inhibiting VEGF-mediated snail nuclear localization: implications for Gleason grading. Cancer Cell 2010, 17:319-332.

16. Vetter $G$, Saumet $A$, Moes $M$, Vallar L, Le Béchec A, Laurini $C$, Sabbah M, Arar K, Theillet C, Lecellier CH, Friederich E: miR-661 expression in SNAl1induced epithelial to mesenchymal transition contributes to breast cancer cell invasion by targeting Nectin-1 and StarD10 messengers. Oncogene 2010, 29:4436-4448.

17. Shin S, Dimitri CA, Yoon SO, Dowdle W, Blenis J: ERK2 but not ERK1 induces epithelial-to-mesenchymal transformation via DEF motifdependent signaling events. Mol Cell 2010, 38:114-127.
18. Xie L, Law BK, Chytil AM, Brown KA, Aakre ME, Moses HL: Activation of the Erk pathway is required for TGF-beta1-induced EMT in vitro. Neoplasia 2004, 6:603-610.

19. Zavadil J, Böttinger EP: TGF-beta and epithelial-to-mesenchymal transitions. Oncogene 2005, 24:5764-5774.

20. Neth P, Ries C, Karow M, Egea V, Ilmer M, Jochum M: The Wnt signal transduction pathway in stem cells and cancer cells: influence on cellular invasion. Stem Cell Rev 2007, 3:18-29.

21. Anjum R, Blenis J: The RSK family of kinases: emerging roles in cellular signaling. Nat Rev Mol Cell Biol 2008, 9:747-758.

22. Doehn U, Hauge C, Frank SR, Jensen CJ, Duda K, Nielsen JV, Cohen MS, Johansen JV, Winther BR, Lund LR, Winther O, Taunton J, Hansen SH, Frödin M: RSK is a principal effector of the RAS-ERK pathway for eliciting a coordinate promotile/invasive gene program and phenotype in epithelial cells. Mol Cell 2009, 35:511-522.

23. Smolen GA, Zhang J, Zubrowski MJ, Edelman EJ, Luo B, Yu M, Ng LW, Scherber CM, Schott BJ, Ramaswamy S, Irimia D, Root DE, Haber DA: A genome-wide RNAi screen identifies multiple RSK-dependent regulators of cell migration. Genes Dev 2010, 24:2654-2665.

24. Roux PP, Richards SA, Blenis J: Phosphorylation of p90 ribosomal S6 kinase (RSK) regulates extracellular signal-regulated kinase docking and RSK activity. Mol Cell Biol 2003, 23:4796-4804.

25. Ghoda L, Lin X, Greene WC: The 90-kDa ribosomal 56 kinase (pp90rsk) phosphorylates the N-terminal regulatory domain of IkappaBalpha and stimulates its degradation in vitro. J Biol Chem 1997, 272:21281-21288.

26. Yoshimura T, Yuhki N, Wang MH, Skeel A, Leonard EJ: Cloning, sequencing, and expression of human macrophage stimulating protein (MSP, MST1) confirms MSP as a member of the family of kringle proteins and locates the MSP gene on chromosome 3. J Biol Chem 1993, 268:15461-15468.

27. Trusolino L, Comoglio PM: cell signalling fo $r$ invasive growth. Nat Rev Cancer 2002, 2:289-300.

28. Wang MH, Zhou YQ, Chen YQ: Macrophage-stimulating protein and RON receptor tyrosine kinase: potential regulators of macrophage inflammatory activities. Scand J Immunol 2002, 56:545-553.

29. Wang MH, Ronsin C, Gesnel MC, Coupey L, Skeel A, Leonard EJ, Breathnach R: Identification of the ron gene product as the receptor for the human macrophage stimulating protein. Science 1994, 266:117-119.

30. Wang $D$, Shen $Q$, Chen $Y Q$, Wang MH: Collaborative activities of macrophage-stimulating protein and transforming growth factor-beta1 in induction of epithelial to mesenchymal transition: roles of the RON receptor tyrosine kinase. Oncogene 2004, 23:1668-1680.

31. Côté M, Miller AD, Liu SL: Human RON receptor tyrosine kinase induces complete epithelial-to-mesenchymal transition but causes cellular senescence. Biochem Biophys Res Commun 2007, 360:219-225.

32. Yao HP, Luo YL, Feng L, Cheng LF, Lu Y, Li W, Wang MH: Agonistic monoclonal antibodies potentiate tumorigenic and invasive activities of splicing variant of the RON receptor tyrosine kinase. Cancer Biol Ther 2006, 5:1179-1186.

33. Zhang Y, Kaplan-Lefko PJ, Rex K, Yang Y, Moriguchi J, Osgood T, Mattson B, Coxon A, Reese M, Kim TS, Lin J, Chen A, Burgess TL, Dussault I: Identification of a novel recepteur d'origine nantais/c-met smallmolecule kinase inhibitor with antitumor activity in vivo. Cancer Res 2008, 68:6680-6687.

34. Wang MH, Montero-Julian FA, Dauny I, Leonard EJ: Requirement of phosphatidylinositol-3 kinase for epithelial cell migration activated by human macrophage stimulating protein. Oncogene 1996, 13:2167-2175.

35. Xu XM, Zhou YQ, Wang MH: Mechanisms of cytoplasmic \{beta\}-catenin accumulation and its involvement in tumorigenic activities mediated by oncogenic splicing variant of the receptor originated from Nantes tyrosine kinase. J Biol Chem 2005, 280:25087-25094.

36. Logan-Collins J, Thomas RM, Yu P, Jaquish D, Mose E, French R, Stuart W, McClaine R, Aronow B, Hoffman RM, Waltz SE, Lowy AM: Silencing of RON receptor signaling promotes apoptosis and gemcitabine sensitivity in pancreatic cancers. Cancer Res 2010, 70:1130-1140.

37. Thobe MN, Gurusamy D, Pathrose P, Waltz SE: The Ron receptor tyrosine kinase positively regulates angiogenic chemokine production in prostate cancer cells. Oncogene 2010, 29:214-226.

38. Smith JA, Poteet-Smith CE, Xu Y, Errington TM, Hecht SM, Lannigan DA: Identification of the first specific inhibitor of p90 ribosomal S6 kinase (RSK) reveals an unexpected role for RSK in cancer cell proliferation. Cancer Res 2005, 65:1027-1034. 
39. Richards SA, Dreisbach VC, Murphy LO, Blenis J: Characterization of regulatory events associated with membrane targeting of $p 90$ ribosomal S6 kinase 1. Mol Cell Biol 2001, 21:7470-7480.

40. Zhang K, Yao HP, Wang MH: Activation of RON differentially regulates claudin expression and localization: role of claudin-1 in RON-mediated epithelial cell motility. Carcinogenesis 2008, 29:552-559.

41. Moreno-Bueno G, Portillo F, Cano A: Transcriptional regulation of cell polarity in EMT and cancer. Oncogene 2008, 27:6958-6969.

42. Wagh PK, Peace BE, Waltz SE: Met-related receptor tyrosine kinase Ron in tumor growth and metastasis. Adv Cancer Res 2008, 100:1-33.

43. Camp ER, Yang A, Gray MJ, Fan F, Hamilton SR, Evans DB, Hooper AT, Pereira DS, Hicklin DJ, Ellis LM: Tyrosine kinase receptor RON in human pancreatic cancer: expression, function, and validation as a target. Cancer 2007, 109:1030-1039.

44. Valacca C, Bonomi S, Buratti E, Pedrotti S, Baralle FE, Sette C, Ghigna C, Biamonti G: Sam68 regulates EMT through alternative splicing-activated nonsense-mediated mRNA decay of the SF2/ASF proto-oncogene. J Cell Biol 2010, 191:87-99.

45. Ma Q, Zhang K, Guin S, Zhou YQ, Wang MH: Deletion or insertion in the first immunoglobulin-plexin-transcription (IPT) domain differentially regulates expression and tumorigenic activities of RON receptor Tyrosine Kinase. Mol Cancer 2010, 9:307-21.

46. Park JS, Park JH, Khoi PN, Joo YE, Jung YD: MSP-induced RON activation upregulates UPAR expression and cell invasiveness via MAPK, AP-1 and NF-\{kappa\}B signals in gastric cancer cells. Carcinogenesis 2011, 32:175-181.

47. Narasimhan M, Ammanamanchi S: Curcumin blocks RON tyrosine kinasemediated invasion of breast carcinoma cells. Cancer Res 2008, 68:5185-5192.

48. Panta GR, Kaur S, Cavin LG, Cortés ML, Mercurio F, Lothstein L, Sweatman TW, Israel M, Arsura M: ATM and the catalytic subunit of DNAdependent protein kinase activate NF-kappaB through a common MEK/ extracellular signal-regulated kinase/p90(rsk) signaling pathway in response to distinct forms of DNA damage. Mol Cell Biol 2004, 24:1823-1835.

49. Torres MA, Eldar-Finkelman H, Krebs EG, Moon RT: Regulation of ribosomal S6 protein kinase-p90(rsk), glycogen synthase kinase 3, and beta-catenin in early Xenopus development. Mol Cell Biol 1999, 19:1427-1437.

50. Pan ZZ, Devaux Y, Ray P: Ribosomal S6 kinase as a mediator of keratinocyte growth factor-induced activation of Akt in epithelial cells. Mol Biol Cell 2004, 15:3106-3113.

51. Lu Y, Yao HP, Wang MH: Multiple variants of the RON receptor tyrosine kinase: biochemical properties, tumorigenic activities, and potential drug targets. Cancer Lett 2007, 257:157-164.

doi:10.1186/1476-4598-10-66

Cite this article as: Ma et al: Ribosomal Protein S6 Kinase (RSK)-2 as a central effector molecule in RON receptor tyrosine kinase mediated epithelial to mesenchymal transition induced by macrophagestimulating protein. Molecular Cancer 2011 10:66.

\section{Submit your next manuscript to BioMed Central and take full advantage of:}

- Convenient online submission

- Thorough peer review

- No space constraints or color figure charges

- Immediate publication on acceptance

- Inclusion in PubMed, CAS, Scopus and Google Scholar

- Research which is freely available for redistribution

Submit your manuscript at www.biomedcentral.com/submit
Ciomed Central 